\title{
Peripheral mobilities \\ Looking at dormant, delegitimized and forgotten \\ transport regimes
}

Massimo Moraglio*

Introduction

Industrialisation and modernity have been, generally speaking, depicted as being established in one country (usually the UK, Western Europe or the USA) and then transferred to other Western Europe or North Atlantic countries. It was only in a later stage that this process reached the globe's periphery and semi-periphery, though, in these latter areas, the transfer process created a limited and "inferior" quality in its outcomes (Wallerstein, 1974). These kinds of technological flows are defined as one-way only, e.g. having a core which "produces" innovations, and a periphery, which "adopts" the novelties (Basalla, 1967). Legitimated by its "superior" technology, the core thus reinforced its political and cultural dominance, building (in a tautological way) the stereotypical concept of Western countries as superior to peripheries (Raina, 1999). A large set of agencies supported this construction, which has been dominant also among the elite ruling the peripheries.

Among the fields in which this model has been fulfilled, infrastructures, mobility and transport are crucial. Reinforcing this Western "superiority", there was not only the technological transfer (e.g. the flows of ideas, people and objects) put in motion by physical movements, but also the very same technologies that allowed those flows (vessels, trains, motor-vehicles and their large technical systems. There

\footnotetext{
*Technische Universität Berlin - TU Berlin.
} 
is, therefore, very little surprise in how the regimes of flows (as movement of persons, goods and information) have largely been conceived and practiced within a Western paradigm, namely massive infrastructural systems, often working under a product-driven approach, with little attention to their environmental, social and economic externalities (Ambrosius, 2014).

Beyond power, the legitimizing elements of this dominance have been efficiency, proficiency and speed, with the latter the crucial factor (Virilio, 1977). Those elements combined were considered indispensable for achieving the expected goals of development and economic growth: the more a country lagged behind in the process of modernization, the more modern transport regimes were considered crucial to fuelling development, pushing for the adoption of new transport systems and massive infrastructural networks. Although it is possible to trace resilience against this model and the coexistence of old and new (Edgerton, 1999), and even open resistance against the development of those transport and infrastructural regimes (Norton, 2011), they are still dominant (Mom et al., 2011).

This has thus led to the marginalisation of "old" transport systems, those not fitting the dominant model, and this happened both in the core and in the peripheries. Non-motorized mobility was particularly put under pressure and unwelcome, considered a mere relict of the past, whose expulsion from the roads should be accomplished as soon as possible (Passalacqua, 2010). Horse- and animal-drawn carts, but also bicycles and, naturally, people walking were subject to constraints, pitied and viewed as being fated to inevitably disappear (Norton, 2012). However, it was not just a marginalisation of devices: it was a world of transport regimes which faded away. Informal and bottom-up mobility practises were largely substituted by formalised and centralised systems: the latter ones, on one hand facilitated mass transport, but on the other hand oversimplified the mobility options available for movements. Western mobility regimes were subjected to strict rules. For instance, after the Great War, there were many examples of collective use of automobiles (from France to Buenos Aires (JTH forthcoming)), both in car-pooling and car-sharing, as well as shared taxis, but already by the 1930s individual ownership and personal use were dominant, and often the only legally accepted models.

Those westernized models were prevailing and fashionable (at least in our imagination), but in the 1960s they were simultaneously displaying their amazing achievements (that is higher mobility for the masses) and their inner contradictions (Ladd, 2008). At the very same moment that transport modernity was reaching its momentum, as in the case of mass motorisation in Europe and Japan, there was the "post-war urban transport model's failure to deliver its promises" (Scheurer et al., 2000, pp. 2-1). Instead of offering individual mobility, mass motorisation delivered 
collective immobility due to congestion and traffic jams. This was quickly followed by the oil crisis, pollution and a growing perception of social exclusion linked to that model (Rosen, 2001). Once transport regimes were seen from this angle, it was possible to define how the dominant transport systems embodied gender, income, ethnic values and bias, and how the global higher rate of mobility was not global but indeed gendered, geographically limited to some parts of the globe and pretty much related to income. The understanding of the environmentally negative externalities of transport practises offered additional and well-grounded reasons to question the current regimes.

At the intersection of those elements stands the need for a fresh approach to transport policies.

\section{Change of foci...}

While there is growing discussion about the limit of today's mobility regimes, it is also true that transport policies still largely focus on progressive trends, great narratives and motorized systems. In the mainstream debate - not only among experts - transport systems were depicted as development triggers, thus as facilitators of economic and personal opportunities (MacKinnon et al., 2008). The idea of a progressive tale of technology advancements (and its corollaries of innovations, great inventions and ingenuity) is central in the debate ${ }^{1}$. Here, again, traditional westernised transport regimes are considered those offering the best outcomes against the classical criterion of efficiency. Wheeled and mechanised mobility still matches the experts' agenda, and it is reinforced by a still dominating desire for private motor-vehicles. All this happens while governments sign agreements (Rio 1992 up to Paris 2015) for environmental protection and other political imperatives about the reduction of $\mathrm{CO}_{2}$ emissions.

At the opposite end of the spectrum, social sciences have investigated transport and mobility with fresh approaches, which has led to a radical change of perspectives. In social sciences, the "dark" sides of transport modernity have fuelled a growing debate about the contradictions of Western mobilities. The concept of "motility" (that is the possibility of moving, see Kaufmann et al., 2004) and the "mobility turn" (Sheller and Urry, 2006) are (among others) two of the flagships of mobility studies, offering fruitful and original approaches. With a different angle, from the 1990s

1. However, we can trace first signs of alternative thinking. Among others, David Metz already in 2008 questioned the relevance of infrastructure investments in transport for saving travellers' time. He suggested that time is never saved, but instead once fed with more infrastructural networks and capacity, yes the drivers save time, but they use the time saved to travel further (Metz, 2008). 
there was a growing investigation of the side effects of Western mass motorisation, showing how an automobile-centred transport regime could trigger social exclusion, affecting those without a car (Lucas, 2012). Again, those research studies showed that social exclusion was largely gendered and income related, hitting the weakest part of the population, such as children and elderly. This has led not only academics but also activists to question the criteria which make a transport regime successful. For example, in a world engaged to reducing $\mathrm{CO}_{2}$ emission, should speed (and its greater use of energy) be a dominant criterion? What about supporting non-motorised transport modes, such as walking and biking, those with low $\mathrm{CO}_{2}$ emissions? Why is the budget dedicated to non-motorised systems and infrastructures such a small percentage of overall transport spending?

In this landscape, I state that we should look critically at the current dominant mobility and look with attention at what I call here peripheral mobilities (Fari and Moraglio, 2015). We should avoid any romanticised visions of the past and its peripheral mobilities, but those systems can still offer us hints and alternative models, those that can better fit the future transport agenda and reduce negative externalities. In order to reach a better understanding of past, present and future mobilities we should therefore change our research avenues. Light technology and out-of-market mobility systems should be better appraised. Walking, using a bike, sharing vehicles without monetary compensation can be examples of "alternative" and truly shared mobilities ( $\mathrm{JTH}, 2018$ ). We need more investigations on shadow economies of transport, such as long-distance coaches, or peer-to-peer car-pooling and car sharing. We should enlarge our focus, well beyond the implicit assumption of useful mobility, usually associated with an adult, white, healthy male: we all know how much mobility is a gendered space, and still this is so little debated! There is a growing attention on these topics, and many investigations are already on the way (Lucas, 2012). But the next step is to reverse the current mainstream, which labels as peripheral whatever is not motorised, privatised and marketable.

Here, the concept of periphery is not just geographical: I suggest looking at hidden, subaltern and forgotten mobilities as experienced today and in the past, both in the peripheries and in the cores. In this respect, we should also address (and rethink) the geographies of mobilities. If we take a change of approach seriously, then we should re-think how we label mobilities: We should stop dismissing mobilities as "backward", "old" and "poor", labels which spread the gospel of "modern" wheeled mobility. Nowadays, North-European countries are acting in favour of pre-modern (or post-modern?) transport models, including bicycling, walking, post-ownership transport, and (try, or pretend to) put "peripheral" mobilities more in the frame. However, all together, despite the claimed shift in mobility trends, "calling for 
innovation is, paradoxically, a common way of avoiding change when change is not wanted" (Edgerton, 2006, p. 210). All the innovations so far proposed in the transport field actually aim to keep transport attitudes as experienced in the past decades, in the heydays of wheeled transport. In other words, many of the promises of better, no-polluting, less expensive cars, at the end of the day, replicate twentieth century western models of mobility.

\section{...and putting users in the frame}

Defining a long-term view of mobility asks us to combine history and future studies, in order to display not only the construction of today's dominant narrative, but also to debunk its rhetoric and its strengths, and thus to outline, with better instruments, the future transition toward a sustainable tomorrow. History, Science and Technology Studies, future studies, and economy must be part of this quest, but we need contributions from geography, sociology and anthropology. Combining different backgrounds will create problems of jargons, agendas and goals: but it will help immensely in better defining new narratives.

One way to address this issue is by asking for greater user participation as beneficial for sustainable transport policies. Nowadays, participatory design, user experience and user involvement are central for the automotive industry, which is - globally - very keen on developing end-user engagement, in order to bring products to market that match customers' requests. On the opposite end of the spectrum, the public transport industry has only recently taken care of customer perspectives. This lack of understanding of users creates a lack of communication, an imprecise consideration of passenger needs, a low level of customer satisfaction and a misunderstanding of social needs. Moreover, missing citizens' needs leaves us with mere top-down policies and practises - as usually performed by transport suppliers. This not only reduces mobility opportunities, but hampers the democratic process and citizens' rights to mobility. According to the European Transport Policy, "users therefore need to be put back at the heart of transport policy" (EC, 2001, p. 64), especially as participating actors in all the stages of public transport policy-making. Promoting this participation, in the long run, produces not just a socially shaped transport system, but also better resource allocation and even better economic performance for transport companies (Schifelbusch and Dienel, 2009).

For this reason, transport structures "cannot be understood solely in terms of their technological components but as complex systems" (Moss, 2000, p. 65). Among the "system builders" of such a system, the users (or, better, here we could say citizens) are truly involved: "Within the possibilities and constraints set by system building 
processes and intrinsic system proprieties, users may use large technical systems in multiple, sometimes surprising ways. Users, too, are agents of Large Technical System-related societal changes" (Van der Vleuten, 2006, p. 294).

\section{Seeking transition and alternatives}

Luckily, there is greater agreement to better take into account the "soft" and social side of the construction of mobility. For better or worse, some sectors of the transport industry, such as automotive, are indeed re-framing their mind-set and their business models, thinking of mobility peak (Metz, 2013) and post-ownership society (Jeekel, 2013). This drives the move from selling products to offering services, crumbling the classical distinction among industrial sectors (WEF, 2013). However, while many praise those innovative models as well as the rise of the sharing economy, we have evidence of their side effects (Slee, 2015). Those trends are impacting social, economic and political arenas, and a multi-faceted investigation is required: but we still witness weak networking opportunities (both in academia and in the realm of policy-making) to discuss the above in a trans-disciplinary way.

We also need a change of pace in the description of mobility. For instance, blanketed under the neutrality of statistics, the most diffuse and globally experienced form of mobility, namely walking, is silenced and it simply disappears (EC, 2013). The statistical silence on walking is itself a question which needs to be investigated: why we know - with little effort - how many aircrafts and passengers landed at London-Heathrow airport on any day of the past, but we have simply no clue on the quantitative relevance of walking and biking? Why do the statistics ignore such a relevant contribution to our everyday experience, to the importance of walking for the economic system, to the social necessity and personal pleasure of walking? The statistical focus on wheeled and motorised is naturally full of consequences: removing walking, biking, using buses or other hidden mobilities from the account delegitimises those systems, making them disappear from the scientific and political debate and, in conclusion, creates an ideology of transport based on heavilytechnologised systems. This statistical repertoire and its ideological corollaries were shaped in the 1920s, and while it fit the political ideologies of those times (Benoit, 2004), it poorly matches today's need for social and environmental sustainability (Oldenziel, 2014).

For instance, private vehicles with electric motors are considered a novelty (but they have a long history back to early 1900s (Mom, 2004), as a sort of Deus ex machine, which will lead us out of the mud of energy wars, deadly polluted urban areas and immobility. Those who are less worried about the environmental issue focus 
their attention on driverless vehicles, in which travelling is a freed time, as if going by train or tram would not giving the same experience (KPMG, 2012).

\section{Working on the debris}

Obsessed with technological up-to-date features, transport policies miss the relevance of "old" technologies, alternative regimes and hidden systems. This argument relies naturally on David Edgerton's work, who suggests how the discussion about technology (also in academia) is obsessed with innovation, while actually in the real world "old" and "dated" technologies are those in everyday use. I push the concept further, claiming that an innovation-prone debate today creates the (social and environmental) failures of tomorrow. In other words, technological driven solutions for today's challenges create also (negative) "externalities"; the latter are dismissed as involuntary failures, which technology itself can successfully fix in the future. To make an example, practically no one denies the negative externalities of the internal combustion engine in cars; the solution is thus suggested to be the electric engine (though electricity is globally produced also by fossil fuel sources, which will create problems in the future).

If the reader allows me to conjecture a little bit, it seems to me that Benjamin's Angelus Novus concept can also be applied to technological obsessions in the transport field. Written in the despair of Nazism dominating Europe, and briefly before Benjamin committed suicide, the Angelus Novus was a central argument in his 1940s "Theses on the philosophy of history". This thesis reflected Benjamin's criticisms of time linearity and a harsh disapproval of Marxist historical materialism. For the German philosopher, in the thesis we have a reversal of the angel of progress, always confidently looking at the future without concerns about the consequences of progress: in Benjamin it is substituted by a different angel, who looks at the past and is truly concerned about the victims of history. In Benjamin, the driving and destroying force of history is the politic. The march of ideologies promises a bright future, but it creates failures and pain, which Benjamin calls "debris".

Benjamin, interpreting progress, wrote that:

A Klee painting named Angelus Novus shows an angel looking as though he [sic] is about to move away from something he is fixedly contemplating. His eyes are staring, his mouth is open, his wings are spread. This is how one pictures the angel of history. His face is turned toward the past. Where we perceive a chain of events, he sees one single catastrophe which keeps piling wreckage upon wreckage and hurls it in front of his feet. The angel would like to stay, awaken the dead, and make whole what has been smashed. But a storm is blowing from 
Paradise; it has got caught in his wings with such violence that the angel can no longer close them. The storm irresistibly propels him into the future to which his back is turned, while the pile of debris before him grows skyward. This storm is what we call progress (Benjamin, [1940] 1968).

Moving back to mobility regimes and troubles, we find a similar progressive tale of future mobility depicted as bright and painless, aware of the failures of the past, but firmly promising new and improved technologies. But this "technological fix" approach will leave more debris, more failures and more pain at the foot of the angel. Let's take the example of energy efficiency: this is seen in se as one of the main contributors to the current environmental crisis, and the role of new technologies is central to achieving a less energy intense mobility network. However, we need a better appraisal of this new and "efficient" transport socio-technical system. Efficiency in the use of resources - and consequently lower costs - drove us straight forward to Jevons' "efficiency paradox" (Wallenborn, 2013): that is in the short term a reduction of the total consumption, but in the medium term an increase of the use of resources.

So, is it not better to move to a non-linear approach, in which progressive tales of progress and technologies leave room for a more complex definition of transport trends? If we frame transport not as a path from the primitive to the sophisticated, in which technologies are one non-linear actor among others, the relevance of "peripheral mobilities" becomes indispensable: indispensable in our ability to debunk mobility history, but even more so in our ability to develop policies which minimize the production of debris... In this regard, I state that peripheral mobilities are the debris produced by western transport regimes, and social sciences and humanities should devote their attention to this clash. In other words, looking at the debris of transport's past trajectory will allow us to better understand how silent and forgotten mobilities worked, what their relevance was, their strengths and their limits. Silent mobilities are voiceless, but they were the everyday experience of millions of people. Silent mobilities are often very vibrant, efficient and effective in fulfilling people's needs and desire, but what do we know about them? I am tempted to say that we are witnessing a damnatio memoriae: peripheral mobilities have not only had a hard time entering the public discussion and policy makers' agenda, but we have lost their histories and their memory. We need more investigations, using the tools of social sciences and humanities, to better (and critically) frame alternative mobility regimes to the dominating ones. Let's take the example of shared taxis (JTH, 2018): the usual history of automobilism is one of privately-owned and privatelyused motor-vehicles, but the forgotten histories (from Paris to Buenos Aires) of 
shared vehicles clash with the traditional main narrative. We know even less about grass-roots car-sharing models in 1930s Italy, those legacies are now traceable only in novels and tales (Gadda, 1939). What we do know about peer-to-peer pre-Uber car-pooling in European cities and villages? Why have we forgotten the impressive 1930s bike-devoted road network around many European cities (Reid, 2017)? Which power and gender relations and unbalances were embedded in those silent tales? Which sort of silent mobilities are experienced today? How can we unveil silent mobilities and make them tools for alternative narratives and practises in the transport realm?

So, in my eyes, in order to figure out a socially and environmentally sustainable future, we should have a better appraisal of silent mobilities, those subjected to damnatio memoriae.

\section{Conclusion}

Despite the dominant narrative of better and environmentally-friendly innovation, transport is a growing energy consumer and a sector with increasing $\mathrm{CO}_{2}$ emissions. This requires a change in the mobility agenda with no hesitation. Such a change can benefit from technological achievements, although, as we have seen, the mainstream of the current debate focuses on innovations as instrumental for maintaining the current motorised and wheeled transport regime based on private vehicles. In this vein, we need to shape - well before new technologies - a new narrative of mobility, which goes beyond simple adjustments of today's regime. We need to critically assess the dominant approach, which legitimises today's regime on speed and efficiency as main performance indicators. This main narrative is obsessed, as we have seen, with technologies, but tends also to forget users according to gender, age and income basis (e.g. women, children, elderly).

In my view, Walter Benjamin's Angelus Novus offers interesting angles, and his criticism of progress also helps to debunk the ideology of technological fixes in transport. In displaying how linear and progressive narratives create that very debris which it should aim to eliminate, Benjamin's criticism can be a powerful tool in investigating history and critically defining future trends. Instead of praising electric cars or autonomous vehicles as the 2030 horizon for transport, we should assess those as creators of tomorrow's debris, and as agents of the reproduction of today's social inequalities and environmental unsustainability. Looking seriously at hidden, forgotten and peripheral mobilities will help us to avoid the trap of a simple management of today, and to frame mobility in 2030 and 2050 in a more inclusive and sustainable way. 


\section{Bibliographic References}

Ambrosius, Gerold. (2014), "Archetypes of international infrastructural integration”. In: SCHifelbusch, Martin \& Dienel, Hans-Liudger (eds.). Linking networks: the formation of common standards and visions for infrastructure development. New York, Ashgate, pp. 35-50.

BASALla, George. (1967), “The spread of Western science: a three-stage model describes the introduction of modern science into any non-European nation". Science, 5 (156): 611-622.

Benjamin, Walter. ([1940] 1968), Illuminations. Edited and with an Introduction by Hannah Arendt. Translated by Harry Zohn. New York, Schocken. The quote reported in this paper is available online at http://members.efn.org/ dredmond/ThesesonHistory.html, accessed 13/9/2017.

Benoît, Godin (ed.). (2004), Measurement and statistics on science and technology: 1920 to the Present. London/New York, Routledge.

DeloitTe. (2012), "Fourth annual Gen Y automotive survey: executive summary of key themes and findings". Available at http://www.deloitte.com/assets/Dcom-UnitedStates/Local\%20 Assets/Documents/us_auto_GenYSurveyReport_02032012.pdf, accessed 31/5/2017.

Edgerton, David. (1999), "From innovation to use: ten eclectic theses on the historiography of technology". History and Technology: An International Journal, 16 (2): 111-136.

EDgerton, David. (2006), The shock of the old: technology and global history since 1900. London, Profile Books.

European Commission, ec. (2001), “White paper: European transport policy for 2010: time to decide. Luxembourg: office for official publications of the European communities". Available at https://ec.europa.eu/transport/sites/transport/files/themes/strategies/ doc/2001_white_paper/lb_com_2001_0370_en.pdf, accessed 31/5/2017.

European Commission, Ec. (2013), "Eu transport in figure”. Available at http://ec.europa. eu/transport/facts-fundings/statistics/doc/2013/pocketbook2013.pdf, accessed 31/5/2017.

Fari, Simone \& Moraglio, Massimo (eds.). (2015), Peripheralflows: mobilities between core(s) and fringe(s) in a historical perspective. Newcastle upon Tyne, Cambridge Scholars Publishing.

FREADRICH, Eva et al. (2015), "Transition pathways to fully automated driving and its implications for the sociotechnical system of automobility". European Journal of Futures Research, 3 (11): 1-11.

Gadda, Carlo Emilio. (1939), Le meraviglie d'Italia. Firenze, Parenti.

GeELs, Frank W. et al. (Eds.). (2012), Automobility in transition? A socio-technical analysis of sustainable transport. New York/London, Routledge.

ITF. (2013), “Spending on transport infrastructure 1995-2011. Trends, policies, data”. Available at http://www.internationaltransportforum.org/Pub/pdf/13SpendingTrends.pdf, accessed $13 / 11 / 2017$.

Jeekel, Hans. (2013), The car-dependent society: a European perspective. Farnham, Ashgate. 
JTH. (2018), "Special issue on shared taxi”. The Journal of Transport History, 39 (1).

Kaufmann, Vincent et al. (2004), "Motility: mobility as capital". International Journal of Urban and Regional Research, 28 (4): 745-756.

KpmG. (2012), “Self-driving cars: the next revolution”. Available at https://www.kpmg.com/US/ en/IssuesAndInsights/ArticlesPublications/Documents/self-driving-cars-next-revolution. pdf, accessed 6/5/2013.

LADD, B. (2008), Autophobia: love and hate in the automotive age. Chicago, University of Chicago Press.

LuCAs, Karen. (2012), “Transport and social exclusion: Where are we now ?”. Transport Policy, 20: 105-113.

Mackinnon, Danny et al. (2008), “Transport and economic development”. In: Knowles, Richard et al. (eds.). Transport geographies: mobilities, flows and spaces. Hoboken, Wiley, pp. 10-28.

Metz, David. (2008), "The myth of travel time saving”. Transport Reviews, 28 (3): 321-336.

Metz, David. (2013), "Peak car and beyond: the fourth era of travel". Transport Reviews, 33 (3): $255-270$.

Mом, Gijs. (2004), The electric vehicle: technology and expectations in the automobile age. Baltimore, MA, Johns Hopkins Univiversity Press.

Moм, Gijs. et al. (2011), “Hop on the bus, Gus”. Transfers, 1 (1): 1-13.

Moss, Timothy. (2000), “Unhearting water flows, uncovering social relations: introducing new waste water technologies in Berlin". Journal of Urban Technology, 7 (1): 63-84.

Norton, Peter. (2011), Fighting traffic: the dawn of the motor age in the American city. Cambridge, MA, MIT Press.

OecD. (2012), "Strategic Transport Infrastructure Needs to 2030". Available at http://www. oecd.org/futures/infrastructureto2030/49094448.pdf, accessed 7/1/2016.

Oldenziel, Ruth. (2014), "Whose mobility? Sustainability $\&$ the politics of traffic counting in the 20th century". 12th Annual Conference of the International Association for the History of Transport, Traffic and Mobility (T2M). Philadelphia.

Passalacqua, Arnauld. (2010), La bataille de la route. Paris, Descartes et Cie.

RaInA, Dhruv. (1999), “From West to Non-West? Basalla's three-stage model revisited”. Science as Culture, 8 (4): 497-516.

REID, Carlton. (2017), Bike boom: the unexpected resurgence of cycling. Washington DC, Island Press.

Rosen, Paul. (2001), “Towards sustainable and democratic urban transport: constructivism, planning and policy". Technology Analysis \& Strategic Management, 13 (1): 117-135.

Sheller, Mimi \& Urry, John. (2006), “The new mobilities paradigm”. Environment and Planning A., 38 (2): 207-226.

SCHeUrer, Jan et al. (2000), Can rail pay? Light rail transit and urban development with value capture funding and joint development mechanisms. Perth, ISTP. 
Schifelbusch, Martin \& Dienel, Hans-Liudger (eds.). (2009), Public transport and its users: the passenger's perspective in planning and customer care. Farnham, Ashgate.

SLEE, Tom. (2015), What's yours is mine: against the sharing economy. New York/London, OR Books.

VAN DER Vleuten, Erik. (2006), “Understanding network societies: two decades of large technical system studies". In: VAN DER Vleuten, Erik \& KaijSer, Arne (eds.). Transnational infrastructures and the shaping of Europe, 1850-2000. Sagamore Beach, MA, Science History Publication.

Virilio, Paul. ([1986] 1977), Speed and politics: an essay on dromology. New York, Semiotext(e).

WALLENBORN, Grégoire. (2013), “The tragedy of energy efficiency: an interdisciplinary analysis of rebound effects”. ECEEE Proceedings. 1-355-15: 133-144.

WALlersteIn, Immanuel. (1974), The modern world system. Vol. I: Capitalist agriculture and the origins of the European world: economy in the sixteenth century. New York/London, Academic Press.

WEF. (2013), “Connected world: transforming travel, transport and supply chains”. Available at http://www3.weforum.org/docs/WEF_MO_ConnectedWorld_Report_2013.pdf, accessed 5/1/2016.

\section{Abstract}

Peripheral mobilities: looking at dormant, delegitimized and forgotten transport regimes

In the transport debate, policy makers seem to be under the spell of a technological determinism, in which innovation Tand novelty are the key concepts. Obsessed with westernised regimes and systems, the current debate misses the relevance of forgotten, peripheral and silent mobilities. In this regard, looking to those peripheral mobilities is not only important for reconstructing our memory, but can also offer tools to build socially and environmentally sustainable transport regimes. I suggest using Walter Benjamin's Angelus Novus to address the past and future of infrastructural systems and the role of "old" regimes. This paper relies on David Edgerton's work, but I push the argument further, claiming that an innovation-prone debate today creates the (social and environmental) failures of tomorrow. While electric cars and driver-less vehicles can be useful tools, we should consider that peripheral mobilities could better address the issue of socially and environmentally sustainable transports systems. Long-term vision can bridge the past and future of transport policies and offer hints to social science, humanity and governance. Keywords: Peripheral; Long-term view; Technological determinism; Transport; Infrastructure. 


\section{Resumo}

Mobilidades periféricas: uma mirada em direção a regimes de transporte adormecidos, deslegitimados e esquecidos

No debate sobre transportes, os criadores de políticas parecem enfeitiçados por um determinismo tecnológico em que inovação e novidade são os conceitos centrais. Obcecados eles por regimes e sistemas ocidentalizados, o debate atual perde a relevância de mobilidades esquecidas, periféricas e silenciosas. Nesse sentido, olhar para essas mobilidades periféricas não é apenas importante para reconstruir nossa memória, mas também pode nos oferecer ferramentas para construir regimes de transporte sustentáveis, do ponto de vista social e ambiental. Sugiro utilizar o Angelus Novus, de Walter Benjamin, para abordar o passado e o futuro de sistemas infraestruturais e o papel dos regimes "velhos". Este artigo se apoia no trabalho de David Edgerton, mas eu levo o argumento além, defendendo que um debate de hoje voltado para a inovação cria os fracassos (sociais e ambientais) de amanhã. Carros elétricos e "sem motoristas" podem ser ferramentas úteis, mas devemos levar em conta que as mobilidades periféricas podem abordar a questão de transportes social e ambientalmente sustentáveis de forma mais eficiente. Uma visão de longo prazo pode ligar o passado e o futuro das políticas de transportes e oferecer sugestões para as Ciências Sociais, a humanidade e a governança.

Palavras-chave: Periférico; Longa duração; Determinismo tecnológico; Transporte; Infraestrutura.

Texto recebido em 8/1/2018 e aprovado em 16/1/2018.

DOI: $10.11606 / 0103-2070 . t s .2018 .142229$

MASSIMO MORAgLIO é pesquisador senior na Technische Universität Berlin (T.U. Berlin). E-mail: massimo.moraglio@tu-berlin.de. 